\section{ANALISIS OPTIMALISASI MODAL KERJA PT UNILEVER INDONESIA TBK}

\author{
FERA MAULINA \\ fmauli.defas@gmail.com \\ Politeknik Tonggak Equator
}

pengelolaan modal kerja,

kebutuhan modal kerja, optimalisasi modal kerja.

\begin{abstract}
This study aims to determine working capital requirements and optimization of working capital at PT Unilever Indonesia Tbk. The form of research used is descriptive and uses secondary data obtained from PT Unilever Indonesia Tbk's 2015-2019 financial statements and other sources obtained from literature studies by studying books and journals that are related to the problem under study. The results showed that (1) PT Unilever Indonesia Tbk's need for working capital in 2016-2019 tends to increase. When compared with the available working capital (current assets), PT Unilever Indonesia is experiencing a lack of working capital to finance the company's operations. This lack of working capital will certainly cause PT Unilever Indonesia Tbk to experience liquidity problems, which is the inability to pay short-term obligations on time. Companies will seek credit as a source of funds in order to increase the fulfillment of current assets wealth needs in order to buy raw materials and even pay for employee salaries and other expenses. (2) PT Unilever Indonesia Tbk's optimal working capital in 2015-2018 tends to increase. The real working capital that is in the company is not optimal where the real working capital is not the same as the optimal working capital obtained. Real working capital less than optimal working capital will hamper or disrupt the smooth production or operational process because the company lacks funds. Even though the existing real working capital is not optimal, the amount obtained is not much lower than the optimal working capital.
\end{abstract}

Keyword: working capital management, workong capital requirements, optimization

of working capital.

ABSTRAK

Penelitian ini bertujuan untuk mengetahui kebutuhan modal kerja dan optimalisasi modal kerja pada PT Unilever Indonesia Tbk. Bentuk penelitian yang digunakan adalah deskriptif dan menggunakan data sekunder yang diperoleh dari laporan keuangan PT Unilever Indonesia Tbk tahun 2015-2019 dan sumber lain yang diperoleh dari studi pustaka dengan mempelajari buku dan jurnal yang berkaitan dengan masalah yang diteliti. Hasil penelitian menunjukkan bahwa (1) Kebutuhan modal kerja PT Unilever Indonesia Tbk tahun 2016-2019 cenderung meningkat. Jika dibandingkan dengan modal kerja yang tersedia (aset lancar), PT Unilever Indonesia mengalami kekurangan modal kerja untuk membiayai operasional perusahaan. Kekurangan 
modal kerja ini tentunya akan menyebabkan PT Unilever Indonesia Tbk mengalami kesulitan likuiditas, yaitu ketidakmampuan membayar kewajiban jangka pendek tepat waktu. Perusahaan akan mencari kredit sebagai sumber dana guna meningkatkan pemenuhan kebutuhan kekayaan aset lancar guna membeli bahan baku bahkan membayar gaji karyawan dan biaya lainnya. (2) Modal kerja optimal PT Unilever Indonesia Tbk pada 2015-2018 cenderung meningkat. Modal kerja riil yang ada di perusahaan belum optimal dimana modal kerja riil tidak sama dengan modal kerja optimal yang diperoleh. Modal kerja riil yang kurang dari modal kerja optimal akan menghambat atau mengganggu kelancaran proses produksi atau operasional karena perusahaan kekurangan dana. Meskipun modal kerja riil yang ada belum optimal, namun jumlah yang diperoleh tidak jauh lebih rendah dari modal kerja optimal.

Kata kunci: pengelolaan modal kerja, kebutuhan modal kerja, optimalisasi modal kerja.

\section{PENDAHULUAN}

Setiap perusahaan yang melakukan kegiatan usaha akan membutuhkan modal kerja. Tersedianya modal kerja dalam jumlah yang cukup agar memungkinkan perusahaan dapat beroperasi secara ekonomis dan tidak mengalami kesulitan keuangan. Besarnya modal kerja harus sesuai dengan kebutuhan perusahaan. Modal kerja yang berlebihan terutama modal kerja dalam bentuk uang tunai dan surat berharga dapat merugikan perusahaan karena menyebabkan berkumpulnya dana yang besar tanpa penggunaan yang produktif. Di samping itu kelebihan modal kerja juga akan menimbulkan pemborosan dalam operasi perusahaan.

Modal kerja yang baik adalah modal kerja yang setiap tahun mengalami kenaikan dan di mana jumlah aktiva lancar harus lebih besar dari hutang lancar, sehingga menggambarkan adanya tingkat keamanan (margin safety) yang baik. Manajemen modal kerja dalam suatu perusahaan diperlukan untuk mengetahui jumlah modal kerja optimal yang dibutuhkan perusahaan tersebut. Manajemen modal kerja adalah kegiatan yang mencakup semua fungsi manajemen atas aktiva lancar dan kewajiban jangka pendek perusahaan.

PT Unilever Indonesia Tbk adalah salah satu perseroan pada sektor industri barang konsumsi di Indonesia. Perusahaan ini pertama kali didirikan dengan nama Lever's Zeepfabrieken N.V. pada 5 Desember 1933. Perusahaan ini kemudian mengalami perubahan nama lebih lanjut menjadi "PT Unilever Indonesia Tbk" pada 30 Juni 1997. pengelolaan modal kerja,

kebutuhan modal kerja, optimalisasi modal kerja. 
Perusahaan yang berkode saham UNVR ini tercatat di Bursa Efek Indonesia sejak 11 Januari 1982 dengan mendaftarkan 15\% sahamnya. Perusahaan ini berkantor pusat di BSD City, Tangerang. Kegiatan usaha dan produk yang dihasilkan meliputi produksi, pemasaran dan distribusi barang-barang konsumsi, termasuk di dalamnya sabun, deterjen, margarin, es krim, bumbu-bumbu masak, kecap, produk-produk kosmetik, minuman dengan bahan pokok teh dan minuman sari buah. Beberapa produk PT Unilever Indonesia Tbk meliputi brand-brand ternama seperti Pepsodent, Lux, Lifebuoy, Dove, Pond's, Sunsilk, Clear, Rexona, Vaseline, Rinso, Molto, Sunlight, Walls, Blue Band, Royco, Bango dan masih banyak lagi. Terdapat enam emiten yang terdaftar dalam sub sektor kosmetik dan keperluan rumah tangga. Laba (Rugi) perusahaan-perusahaan tersebut dapat dilihat di tabel 1 .

\section{Tabel 1}

Laba Bersih Perusahaan Yang Terdaftar Dalam Sub Sektor Kosmetik dan Keperluan Rumah Tangga Di BEI Periode 2017 (Dalam Jutaan Rupiah)

\begin{tabular}{|c|l|l|c|}
\hline No. & $\begin{array}{c}\text { Kode } \\
\text { Saham }\end{array}$ & \multicolumn{1}{|c|}{ Nama Emiten } & Laba (Rugi) \\
\hline 1. & UNVR & PT Unilever Indonesia Tbk & $7,004,562$ \\
\hline 2. & TCID & PT Mandom Indonesia Tbk & 179,126 \\
\hline 3. & KINO & PT Kino Indonesia Tbk & 110,417 \\
\hline 4. & ADES & PT Akasha Wira International Tbk & 38,242 \\
\hline 5. & MRAT & PT Mustika Ratu Tbk & $(1,320)$ \\
\hline 6. & MBTO & PT Martina Berto Tbk & $(24,184)$ \\
\hline
\end{tabular}

Sumber: Data Olahan, 2020

PT Unilever Indonesia Tbk melepas sahamnya untuk pertama kali pada tahun 1981. PT Unilever Indonesia Tbk memiliki berbagai merk dan jenis produk yang ditawarkan. Dalam tabel 1.1, dapat dilihat bahwa PT Unilever Indonesia Tbk memiliki laba terbesar diantara perusahaan lainnya dalam sub sektor kosmetik dan keperluan rumah tangga. Jumlah aset, jumlah liabilitas, jumlah ekuitas, penjualan bersih dan laba PT Unilever Indonesia Tbk dapat dilihat dalam tabel 2 di bawah ini. pengelolaan modal kerja,

kebutuhan modal kerja, optimalisasi modal kerja. 
Tabel 2

Jumlah Aset, Jumlah Liabilitas, Jumlah Ekuitas, Penjualan Bersih dan Laba PT Unilever Indonesia Tbk Periode 2015 Hingga 2019 (Dalam Jutaan Rupiah)

\begin{tabular}{cccccc}
\hline Tahun & Jumlah Aset & $\begin{array}{c}\text { Jumlah } \\
\text { Liabilitas }\end{array}$ & $\begin{array}{c}\text { Jumlah } \\
\text { Ekuitas }\end{array}$ & $\begin{array}{c}\text { Penjualan } \\
\text { Bersih }\end{array}$ & Laba \\
\hline 2015 & $15,729,945$ & $10,902,585$ & $4,827,360$ & $36,484,030$ & $5,851,805$ \\
\hline 2016 & $16,745,695$ & $12,041,437$ & $4,704,258$ & $40,053,732$ & $6,390,672$ \\
\hline 2017 & $18,906,413$ & $13,733,025$ & $5,173,388$ & $41,204,510$ & $7,004,562$ \\
\hline 2018 & $20,326,869$ & $12,943,202$ & $7,383,667$ & $41,802,073$ & $9,081,187$ \\
\hline 2019 & $20,649,371$ & $15,367,509$ & $5,281,862$ & $42,922,563$ & $7,392,837$ \\
\hline
\end{tabular}

Sumber: Laporan Tahunan PT Unilever Indonesia, Tbk Periode 2015-2019

Berdasarkan tabel 2 di atas, dapat kita lihat bahwa jumlah aset PT Unilever Indonesia Tbk terus bertambah setiap tahunnya. Dari tahun 2013 hingga 2017, jumlah aset terbanyak adalah di tahun 2019 yaitu sebanyak Rp20,6 triliun. Jumlah liabilitas terus meningkat sepanjang periode 2015 hingga 2019. Hal ini terjadi seiring dengan peningkatan pinjaman bank setiap tahunnya.

Jumlah ekuitas berfluktuasi pada tahun 2015-2019 . Pada tahun 2015, jumlah ekuitas PT Unilever Indonesia Tbk senilai Rp4,8 triliun menurun menjadi Rp4,7 triliun di tahun 2016 kemudian mengalami kenaikan menjadi senilai Rp5,1 triliun di tahun 2017 dan meningkat kembali menjadi Rp7,3 triliun di tahun 2018. Sedangkan mengalami penurunan pada tahun Rp5,2 triliun. Penjualan bersih PT Unilever Indonesia Tbk juga terus meningkat. Sedangkan laba perusahaan cenderung meningkat, hanya pada tahun 2019 laba perusahaan yang mengalami penurunan.

Modal kerja optimal adalah bagian kebutuhan modal yang dipenuhi dengan pinjaman jangka panjang yang beban biaya modalnya lebih murah dibandingkan dengan pinjaman jangka pendek, karena perusahaan dapat memutarkan kelebihan modal kerja yang sementara tidak digunakan untuk mendapatkan penghasilan. Untuk menentukan modal kerja optimal perlu memperhatikan jangka waktu kritis, yaitu lamanya waktu yang menunjukkan besarnya biaya modal pinjaman jangka panjang sama besar dengan biaya modal jangka pendek.

Salah satu alat ukur untuk menentukan keefektifan manajemen modal kerja menurut Kasmir (2015:182) "adalah diukur dari perputaran modal kerja atau working 
capital turnover selama periode tertentu". Artinya seberapa banyak modal kerja berputar selama suatu periode merupakan salah satu rasio untuk mengukur atau menilai keefektifannya modal kerja perusahaan selama periode tertentu. Artinya,.

Mengukur perputaran modal kerja adalah dengan cara membandingkan antara penjualan dengan modal kerja atau dengan modal kerja rata-rata. Penjualan yang akan dibandingkan adalah penjualan bersih (net sales) dalam suatu periode. Sedangkan pembandingnya adalah modal kerja dalam arti seluruh total aktiva lancar (current assets) atau dapat pula digunakan model kerja rata-rata. Pengukuran ini sebaiknya menggunakan dua periode atau lebih sebagai data pembanding, sehingga memudahkan kita untuk menilainya. Berdasarkan uraian dan laporan keuangan PT Unilever Indonesia Tbk, penulis tertarik untuk mengetahui lebih lanjut tentang "Analisis Optimalisasi Modal Kerja PT Unilever Indonesia Tbk”

\section{Rumusan Masalah}

1. 1.Berapa modal kerja yang dibutuhkan PT Unilever Indonesia Tbk tahun 20152019 ?

2. Apakah pengelolaan modal kerja PT Unilever Indonesia Tbk tahun 2015-2019 sudah optimal?

\section{Tujuan Penelitian}

1. Untuk menganalisis kebutuhan modal kerja pada PT Unilever Indonesia Tbk tahun 2015-2019.

2. Untuk menganalisis modal kerja optimal pada PT Unilever Indonesia Tbk tahun 2015-2019.

\section{TINJAUAN PUSTAKA}

\section{Pengertian Modal Kerja}

Menurut Kasmir (2015), "Dana sebagai modal kerja merupakan dana yang digunakan untuk membiayai kegiatan operasional perusahaan, terutama yang memiliki jangka waktu pendek”. Modal kerja menjadi penunjang berdirinya suatu perusahaan. Artinya, modal kerja digunakan untuk memenuhi kebutuhan dalam kegiatan 
operasional suatu perusahaan. Menurut Bringham dan Houston (2011) adapun definisi dasar modal kerja yaitu:

1. Modal kerja (Working Capital), kadang disebut modal kerja bruto, secara sederhana mengacu pada aset lancar yang digunakan dalam operasi.

2. Modal kerja bersih (Net Working Capital) didefinisikan sebagai aset lancar pengelolaan modal kerja,

kebutuhan modal kerja, optimalisasi modal kerja. dikurangi seluruh kewajiban lancar.

3. Modal kerja operasi bersih (Net Operating Working Capital) didefinisikan sebagai aset lancar dikurangi kewajiban lancar yang tidak dikenakan bunga (utang usaha dan akrual).

4. Siklus konversi kas (Cash Conversion Cycle-CCC) adalah berapa lama dana terikat dalam modal kerja, atau berapa lama waktu antara pembayaran untuk modal kerja dan penagihan kas dari penjualan modal kerja tersebut.

\section{Konsep Modal Kerja}

Setiap modal kerja memiliki konsep yang berbeda-beda. Konsep ini dibedakan berdasarkan bagaimana perputaran modal yang dimiliki untuk memenuhi kebutuhan perusahaan, baik dalam hal pemenuhan kebutuhan jangka pendek, perbandingan aktiva lancar dengan utang lancar, maupun perolehan laba. Menurut Kasmir (2015), terdapat tiga macam konsep modal kerja yaitu:

\section{Konsep kuantitatif}

Modal kerja adalah seluruh aktiva lancar (Gross Working Capital). Dalam konsep ini adalah bagaimana mencukupi kebutuhan dana untuk membiayai operasi perusahaan jangka pendek. Jumlah aktiva lancar belum menjamin margin of safety bagi perusahaan. Kelemahan pada konsep ini yaitu tidak mencerminkan tingkat likuiditas perusahaan serta tidak mementingkan kualitas apakah modal kerja dibiayai oleh utang jangka panjang atau jangka pendek atau pemilik modal.

\section{Konsep kualitatif}

Menitikberatkan kepada kualitas modal kerja. Konsep ini melihat selisih antara jumlah aktiva lancar dengan kewajiban lancar. Konsep ini disebut modal kerja bersih atau (Net Working Capital). Dalam penerapan konsep ini, perusahaan dapat melihat tingkat likuiditas. 


\section{Konsep fungsional}

Menekankan kepada fungsi dana yang dimiliki perusahaan dalam memperoleh laba. Artinya sejumlah dana yang dimiliki dan digunakan perusahaan untuk meningkatkan modal kerja seharusnya dapat meningkatkan perolehan laba.

\section{Arti Penting dan Tujuan Modal Kerja}

Menurut peranannya, modal kerja memiliki arti yang sangat penting bagi kegiatan operasional suatu perusahaan. Di samping itu, modal kerja harus dikelola dengan baik agar perusahaan dapat mencapai tujuan tertentu. Pengelolaan modal kerja yang baik dapat meningkatkan likuiditas serta memaksimalkan perolehan laba. Kinerja manajemen suatu perusahaan dapat dinilai setelah mengtahui kecukupan modal kerjanya. Menurut Kasmir (2015), modal kerja memiliki arti penting bagi perusahaan terutama bagi kesehatan keuangan perusahaan yaitu:

1. Kegiatan seorang manajer keuangan lebih banyak dihabiskan dalam kegiatan operasional perusahaan dari waktu ke waktu. Ini merupakan manajemen modal kerja.

2. Investasi dalam aktiva lancar cepat dan serinig kali mengalami perubahan serta cenderung labil, sedangkan aktiva lancar adalah modal kerja perusahaan, artinya perubahan tersebut akan berpengaruh terhadap modal kerja.

3. Separuh dari total aktiva merupakan bagian dari aktiva lancar yang merupakan modal kerja perusahaan. Dengan kata lain, jumlah aktiva lancar sama atau lebih dari $50 \%$ dari total aktiva.

4. Bagi perusahaan yang relatif kecil, fungsi modal kerja amat penting. Perusahaan kecil, relatif terbatas untuk memasuki pasar dengan modal besar dan jangka panjang. Pendanaan perusahaan lebih mengandalkan pada utang jangka pendek, seperti utang dagang, utang bank satu tahun yang tentunya dapat mempengaruhi modal kerja.

5. Terdapat hubungan yang erat antara pertumbuhan penjualan dengan kebutuhan modal kerja. Kenaikan penjualan berkaitan dengan tambahan, piutang, sediaan, dan juga saldo kas. Dan apabila terjadi penurunan penjualan akan berpengaruh terhadap komponen dalam aktiva lancar. pengelolaan modal kerja, kebutuhan modal kerja, optimalisasi modal kerja. 
Manajemen modal kerja dilakukan suatu perusahaan untuk tujuan tertentu, yaitu untuk mengontrol serta memperbaiki kinerja perusahaan. Apabila modal kerja tidak dikelola dengan baik, perusahaan akan kesulitan mengelola seluruh kegiatan operasional. Menurut Kasmir (2015), adapun tujuan dari manajemen modal kerja yaitu:

1. Guna memenuhi kebutuhan likuiditas perusahaan.

2. Dengan modal kerja yang cukup perusahaan memiliki kemampuan untuk memenuhi kewajiban pada waktunya.

3. Memungkinkan perusahaan untuk memiliki sediaan yang cukup dalam rangka memenuhi kebutuhan pelanggannya.

4. Memungkinkan perusahaan untuk memperoleh tambahan dana dari para kreditor, apabila rasio keuangannya memenuhi syarat.

5. Memungkinkan perusahaan memberi syarat kredit yang menarik minat pelanggan dengan kemampuan yang dimilikinya.

6. Guna memaksimalkan penggunaan aktiva lancar guna meningkatkan penjualan dan laba.

7. Melindungi diri apabila terjadi krisis modal kerja akibat turunnya nilai aktiva lancar; dan tujuan lainnya.

\section{Faktor-faktor yang Mempengaruhi Modal Kerja}

Menurut Bringham dan Houston (2011), "Modal Kerja (Working Capital) merupakan seluruh aset jangka pendek, atau aset lancar-kas, efek yang dapat diperjualbelikan, persediaan, dan piutang usaha". Komponen-komponen dalam modal kerja memiliki nilai angka yang berubah-ubah. Hal ini dikarenakan adanya pengaruh dari kegiatan operasional perusahaan. Menurut Sutrisno (2005), adapun faktor-faktor yang mempengaruhi besar kecilnya modal kerja antara lain berubahnya aktiva tetap, berubahnya hutang jangka panjang, berubahnya jumlah modal, laba dan rugi operasi, penyusutan, dan pembayaran dividen.

\section{Perputaran Modal Kerja}

Menurut Kasmir (2015), Perputaran Modal Kerja atau Working Capital Turnover adalah suatu rasio yang digunakan dalam mengukur keefektifan modal kerja pengelolaan modal kerja,

kebutuhan modal kerja, optimalisasi modal kerja. 
perusahaan selama periode tertentu. Dalam arti, berapa banyak modal kerja berputar selama suatu periode tersebut. Untuk mengukur rasio ini kita membandingkan penjualan bersih dengan modal kerja atau dengan modal kerja rata-rata. Dari hasil perhitungan, apabila perputaran modal kerja rendah berarti pengelolaan modal kerja belum efektif dan sebaliknya apabila perputaran modal kerja tinggi berarti modal kerja perusahaan telah efektif. Rumus untuk mengukur perputaran modal kerja sebagai berikut:

$$
\text { Perputaran Modal Kerja }=\frac{\text { Penjualan Bersih }}{\text { Modal Kerja/Modal Kerja Rata-rata }}
$$

\section{Metode Penentuan Modal Kerja Optimal}

Menurut Sutrisno (2005) Penentuan kebutuhan besarnya modal kerja menggunakan beberapa metode, yaitu:

a. Metode keterikatan dana

Yang mempengaruhi penentuan besarnya modal kerja dengan metode ini ada 2 faktor, yaitu:

1) Periode terikatnya modal kerja

Merupakan jangka waktu mulai kas ditanamkan ke dalam elemen-elemen modal kerja sampai menjadi kas lagi. Semakin lama periode keterkaitannya modal kerja akan semakin memperbesar jumlah kebutuhan modal kerja, demikian bila periode terikatnya modal kerja semakin kecil kebutuhan modal kerja juga semakin kecil.

2) Proyeksi kebutuhan kas rata-rata per hari

Pengeluaran kas per hari merupakan pengeluaran rata- rata setiap harinya untuk keperluan bahan baku, pembayaran tunai lainnya.

b. Metode perputaran modal kerja

Metode perputaran modal kerja ditentukan dengan cara perputaran elemen-elemen pembentuk modal kerja seperti perputaran kas, perputaran piutang, dan perputaran persediaan. Dalam penentuan besarnya modal kerja maka dilakukan dengan cara perputaran elemen modal kerja seperti berikut: 


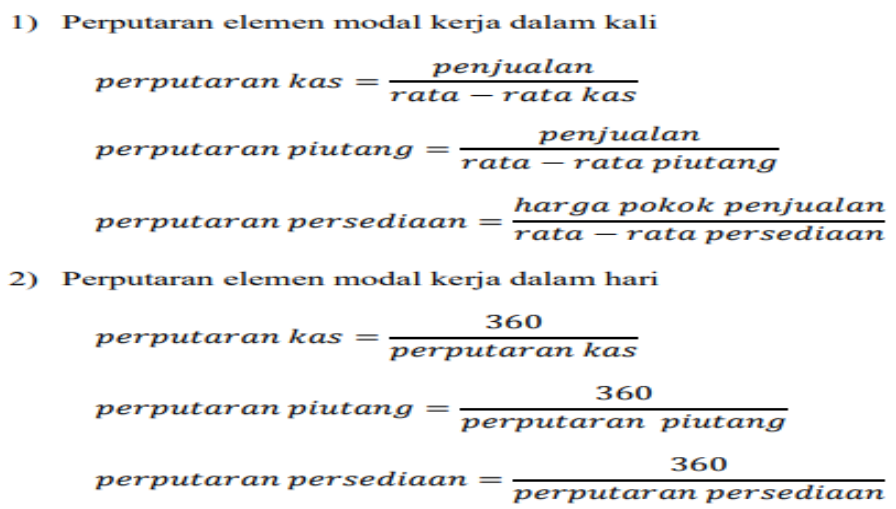

pengelolaan modal kerja, kebutuhan modal kerja, optimalisasi modal kerja.

\section{c. Metode aliran kas}

Aliran kas yang terjadi di perusahaan adalah terus menerus selama perusahaan beroperasi yang terdiri dari aliran kas masuk dan aliran kas keluar. Aliran kas masuk ke perusahaan misalnya perolehan pendapatan berupa hasil penjualan. Uang kas masuk dapat pula diperoleh dari bunga hasil investasi atau pendapatan diluar usaha serta dapat juga diperoleh dari pinjaman pihak lain. Apabila jumlah kas terlalu kecil akan berbahaya bagi perusahaan, karena akan mengakibatkan hambatan bagi pengeluaran untuk berbagai pembayaran perusahaan. Sebaliknya apabila uang kas terlalu besar ketimbang pengeluaran kas yang dibutuhkan juga kurang baik, karena kemungkinan ada uang menganggur atau tidak memberikan penghasilan kepada perusahaan. Aliran kas keluar meliputi pengeluaran biaya bahan baku, tenaga kerja langsung dan biaya pabrik lain (overhead), pengeluaran biaya administrasi umum dan admistrasi penjualan untuk pembelian aktiva tetap.

\section{Penentuan Modal Kerja Optimal}

Menurut Tampubolon (2004) manajemen modal kerja bertujuan untuk mencari tingkat (level) dari susunan aktiva lancar dan pasiva lancar yang optimal. Modal kerja optimal adalah kemampuan perusahaan untuk memaksimalkan hasil (output), dalam arti tidak terjadi kelebihan atau kekurangan modal kerja, sehingga pada tingkat modal kerja optimal yaitu biaya akan sama dengan manfaatnya. Ada 2 hal yang mempengaruhi penentuan modal kerja optimal yaitu:

1. Pertimbangan likuiditas, untuk menentukan pertimbangan likuiditas ada 3 alternatif: 
a. Apabila likuiditas perusahaan tinggi maka aktiva lancar yang dimiliki perusahaan semakin besar sehingga penghasilan (output) makin banyak.

b. Apabila likuiditas perusahaan sedang maka aktiva lancar yang dimiliki pengelolaan modal kerja,

kebutuhan modal kerja, optimalisasi perusahaan rendah sehingga jumlah output sama.

2. Trade-off antara profitabilitas dan resiko

a. Perusahaan ingin profitabilitas tinggi, maka harus memelihara aktiva lancar relatif rendah, akibatnya resiko tinggi terhadap kekurangan persediaan atau kehilangan kesempatan penjualan.

b. Perusahaan ingin resiko terhadap kekurangan persediaan atau kehilangan kesempatan penjualan, maka harus memelihara tingkat aktiva lancar yang relatif, akibatnya profitabilitas rendah.

Analisis optimalisasi merupakan salah satu penentuan besarnya aktiva lancar dengan metode perputaran modal kerja yang didasarkan pada data historis, sehingga kondisi tahun mendatang diasumsikan mirip dengan tahun sebelumnya. Dasar utama untuk menentukan besarnya estimasi modal kerja tahun mendatang adalah hasil estimasi nilai penjualan tahun mendatang. Metode seperti kas, surat berharga, piutang dagang, dan persediaan.

Berdasarkan hasil perputaran elemen aktiva lancar diketahui besarnya perputaran modal kerja. Setelah estimasi nilai penjualan tahun mendatang dengan perputaran modal kerja dapat dihitung nilai modal optimal tahun mendatang. Sehingga didapatkan rumus untuk menghitung Modal Kerja Optimal adalah sebagai berikut:

$$
\text { Modal Kerja Optimal }=\frac{\text { Penjualan yang akan datang }}{\text { Perputaran Modal Kerja }}
$$

\section{METODE PENELITIAN}

\section{Bentuk Penelitian}

Di dalam penelitian ini, penulis menggunakan bentuk penelitian deskriptif dengan pendekatan studi kasus pada PT Unilever Indonesia Tbk. Menurut Purwanto dan Sulistyastuti (2017) "Penelitian deskriptif adalah teknik analisa yang memberikan informasi hanya mengenai data yang diamati dan tidak bertujuan menguji hipotesis serta menarik kesimpulan yang digeneralisasikan terhadap populasi”. Objek yang 
diteliti dalam penelitian ini yaitu laporan keuangan pada PT Unilever Indonesia Tbk. Di dalam penelitian ini, penulis meneliti pada laporan PT Unilever Indonesia Tbk. Waktu penelitian mencakup laporan keuangan perusahaan dari tahun 2015 hingga tahun 2019.

\section{Data yang Digunakan}

Penelitian ini akan menggunakan data sekunder di mana data yang diperoleh untuk kemudian diolah yang didapatkan tidak secara langsung dengan teknik pengumpulan data berupa studi dokumentasi didapatkan dari data keuangan perusahaan PT Unilever Indonesia Tbk tahun 2015-2019. Sedangkan teknik pengumpulan data berupa studi pustaka adalah informasi yang diperoleh dari literatur-literatur yang relevan dan terkait dalam penelitian ini.

\section{Metode Analisis}

Penelitian ini akan menggunakan metode analisis kuantitatif. Menurut Sugiyono (2005), "Untuk penelitian dengan pendekatan kuantitatif, maka teknik analisis data ini berkenaan perhitungan untuk menjawab rumusan masalah dan pengujian hipotesis yang diajukan". Teknik analisis data yang penulis gunakan adalah kuantitatif, yang didukung oleh data Laporan Keuangan PT Unilever Indonesia Tbk tahun 2015-2019 .

"Penelitian (research) akuntansi yang ada pengukuran variabelnya sehingga menghasilkan angka disebut penelitian kuantitatif sedangkan penelitian akuntansi yang tidak ada pengukuran variabel disebut penelitian kualitatif. Pengukuran variabel yang menghasilkan angka ini baik menggunakan satuan moneter, rumus akuntansi, rasio keuangan maupun menggunakan skala" (Muchson, 2015)

\section{HASIL PENELITIAN}

Analisis Kebutuhan Modal Kerja pada PT Unilever Indonesia Tbk Tahun 2015-2019.

Sebagai perusahaan industri PT Unilever Indonesia Tbk memerlukan modal kerja yang cukup besar. Modal kerja tersebut digunakan perusahaan dalam bentuk investasi dalam bahan baku, barang dalam proses dan barang jadi. Apabila jumlah aktiva lancar terlalu kecil, maka akan menimbulkan situasi ilikuid yang artinya perusahaan 
mempunyai hutang lancar yang lebih besar daripada aktiva lancarnya, sedangkan apabila aktiva lancar yang terlalu besar akan berakibat timbulnya aktiva lancar atau dana yang menganggur.

Pengelolaan modal kerja yang baik selain akan lebih memperlancar aktivitas perusahaan juga dapat meningkatkan keberhasilan usaha untuk mendapatkan keuntungan yang diharapkan. Metode perputaran modal kerja merupakan metode untuk menentukan kebutuhan modal kerja dengan memperhatikan perputaran elemen pembentuk modal kerja itu sendiri seperti: kas, piutang usaha dan persediaan. Berikut ini perhitungan perputaran elemen pembentuk modal kerja adalah sebagai berikut:

\section{Perputaran Kas}

Perputaran kas digunakan untuk melihat seberapa besar kas perusahaan mampu menghasilkan penjualan. Tingkat perputaran kas merupakan ukuran efisiensi penggunaan kas yang dilakukan oleh perusahaan. Tingkat perputaran kas menggambarkan kecepatan arus kas kembalinya kas yang telah ditanamkan di dalam modal kerja. Berikut ini disajikan perhitungan perputaran kas PT Unilever Indonesia Tbk tahun 2015-2019.

Tabel 3

Perputaran Kas PT Unilever Indonesia Tbk.Tahun 2015-2019 (dalam jutaaan Rupiah)

\begin{tabular}{|c|c|c|c|c|c|c|}
\hline \multirow{2}{*}{ Tahun } & \multirow{2}{*}{$\begin{array}{c}\text { Penjualan } \\
\text { Bersih }\end{array}$} & \multirow{2}{*}{$\begin{array}{c}\text { Kas } \\
\text { Awal }\end{array}$} & \multirow{2}{*}{ Kas Akhir } & \multirow{2}{*}{$\begin{array}{c}\text { Rata-Rata } \\
\text { Kas }\end{array}$} & \multicolumn{2}{|c|}{ Perputaran Kas } \\
\hline & & & & & Kali & Hari \\
\hline 2015 & $36,484,030$ & 859,127 & 628,159 & 743,643 & 49.06 & 7.34 \\
\hline 2016 & $40,053,732$ & 628,159 & 373,835 & 500,997 & 79.95 & 4.50 \\
\hline 2017 & $41,204,510$ & 373,835 & 404,784 & 778,619 & 52.92 & 6.80 \\
\hline 2018 & $41,802,073$ & 404,784 & 351,667 & 756,451 & 55.26 & 6.51 \\
\hline 2019 & $42,922,563$ & 351,667 & 628,649 & 980,316 & 43.78 & 8.22 \\
\hline
\end{tabular}

Sumber Data: Data Olahan, 2020 


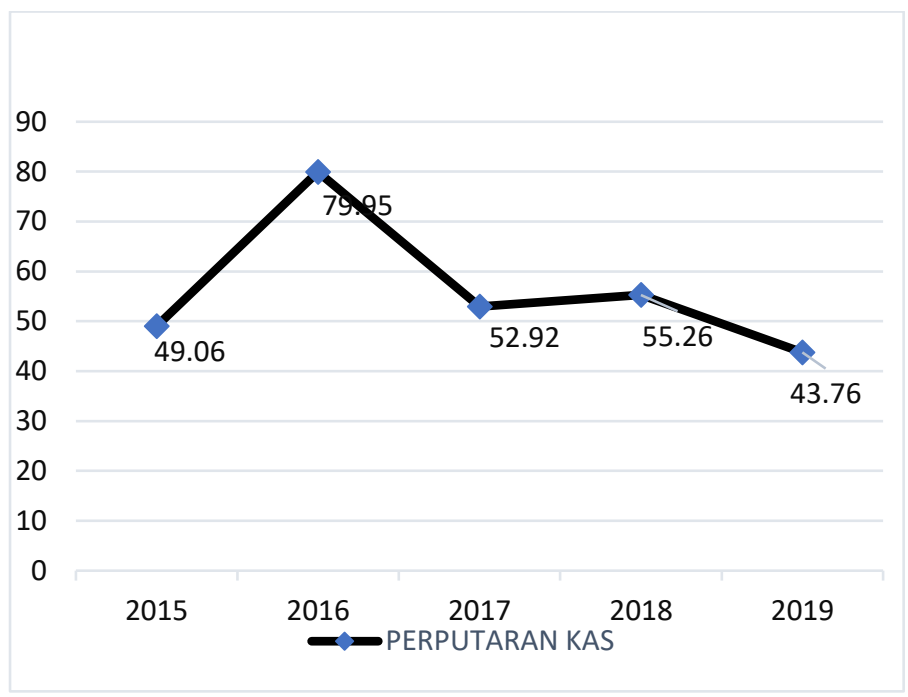

pengelolaan

modal kerja,

kebutuhan

modal kerja,

optimalisasi

modal kerja.

Gambar 1

Perputaran Kas PT Unilever Indonesia Tbk Tahun 2015-2019

Sumber : data olahan, 2020

Berdasarkan gambar 1 dapat dilihat bahwa kemampuan PT Unilever Indonesia Tbk. dalam melakukan perputaran kas periode 2015-2019 berfluktuasi tiap tahunnya. Pada tahun 2015 kas berputar dalam menghasilkan penjualan sebanyak 49,06 kali atau 7,43 hari dalam setahun. Tahun 2016 merupakan perputaran kas yang paling cepat dalam menghasilkan penjualan, yaitu sebanyak 79,95 kali atau 4,50 hari. Pada tahun 2017 hingga 2019 perputaran kas cenderung menurun. Pada tahun 2017 perputaran kas sebanyak 52,92 kali atau hari 6,80 hari. Pada tahun 2018 perputaran kas sebanyak 55,26 kali atau 6,51 hari. Hal tersebut masih tergolong baik, karena perubahan kembali aset lancar menjadi kas melalui penjualan paling lama di tahun 2019, yaitu sebanyak 43,76 kali atau 8,22 hari. Semakin tinggi tingkat perputaran kas berarti semakin efisien tingkat penggunaan kasnya dan sebaliknya semakin rendah tingkat perputarannya semakin tidak efisien, karena semakin banyak uang yang berhenti atau tidak dipergunakan.

\section{Perputaran Piutang Usaha}

Rasio ini menunjukkan berapa lama piutang usaha dapat tertagih, atau dengan kata lain waktu yang dibutuhkan perusahaan untuk merubah piutang menjadi uang tunai. Perputaran Piutang (Receivable Turnover) bagi perusahaan sangatlah penting untuk diketahui karena makin tinggi perputaran piutang, maka piutang yang dapat 
ditagih oleh perusahaan makin banyak. Tertagihnya piutang usaha akan memperkecil adanya piutang yang tidak tertagih dan memperlancar arus kas. Berikut ini disajikan perhitungan perputaran piutang PT Unilever Indonesia Tbk tahun 2015-2019.

Tabel 4

Perputaran Piutang Usaha PT Unilever Indonesia Tbk Tahun 2015-2019 (dalam jutaaan Rupiah)

\begin{tabular}{|c|c|c|c|c|c|c|}
\hline \multirow[t]{2}{*}{ Tahun } & \multirow{2}{*}{$\begin{array}{c}\text { Penjualan } \\
\text { Bersih }\end{array}$} & \multirow{2}{*}{$\begin{array}{c}\text { Piutang } \\
\text { Usaha Awal }\end{array}$} & \multirow{2}{*}{$\begin{array}{c}\text { Piutang } \\
\text { Usaha } \\
\text { Akhir }\end{array}$} & \multirow{2}{*}{$\begin{array}{c}\text { Rata-Rata } \\
\text { Piutang } \\
\text { Usaha }\end{array}$} & \multicolumn{2}{|c|}{$\begin{array}{c}\text { Perputaran } \\
\text { Piutang Usaha }\end{array}$} \\
\hline & & & & & Kali & Hari \\
\hline 2015 & & & $3,244,626$ & $3,070,071$ & & \\
\hline & & & $3,708,257$ & & & \\
\hline & & & $4,715,754$ & $4,212,006$ & 9.78 & 36.80 \\
\hline 2018 & $41,802,073$ & $4,715,754$ & $4,983,471$ & $4,849,613$ & 8.62 & 41.76 \\
\hline 2019 & $42,922,563$ & $4,983,471$ & $5,335,489$ & $5,159,480$ & 8.32 & 43.27 \\
\hline
\end{tabular}

Sumber Data: Data Olahan, 2020

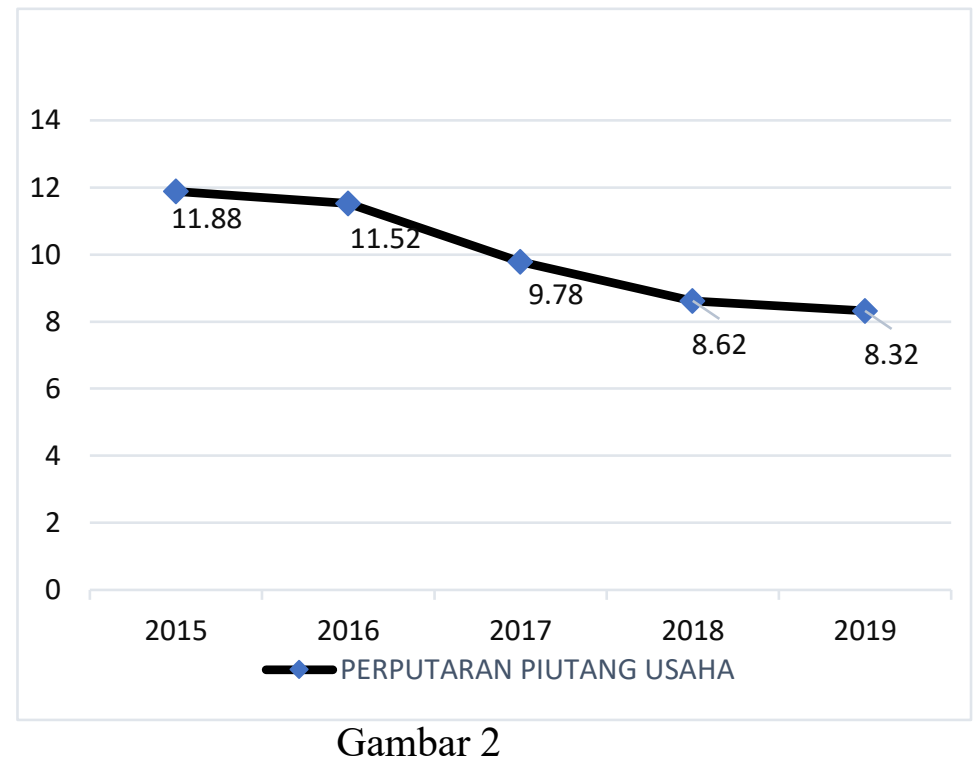

Perputaran Piutang Usaha PT Unilever Indonesia Tbk Tahun 2015-2019 Sumber : data olahan, 2020

Berdasarkan gambar 2 dapat dilihat bahwa kemampuan PT Unilever Indonesia Tbk. dalam melakukan perputaran piutang usaha periode 2015-2019 mengalami penurunan tiap tahunnya. Penurunan ini menandakan terjadinya lambatnya dalam perputaran 
piutang usaha. Perputaran piutang usaha menunjukkan efisiensi perusahaan dalam mengelola piutangnya. Rendahnya perputaran piutang usaha menunjukkan efisiensi penagihan yang kurang baik selama periode tertentu karena lamanya penagihan dilakukan.

Persentase peningkatan rata-rata piutang usaha lebih besar dari persentase peningkatan penjualan tiap tahunnya. Pada tahun 2015 perputaran usaha sebanyak 11,88 kali atau rata-rata pengumpulan piutang usaha adalah 30,29 hari, tahun 2016 sebanyak 11,52 kali atau rata-rata pengumpulan piutang usaha adalah 31,25 hari, tahun 2017 sebanyak 9,78 kali atau rata-rata pengumpulan piutang usaha adalah 36,80 hari, tahun 2018 sebanyak 8,62 kali atau rata-rata pengumpulan piutang usaha adalah 41,76 hari sedangkan 2019 sebanyak 8,32 kali atau rata-rata pengumpulan piutang usaha adalah 43,27 hari.

\section{Perputaran Persediaan}

Rasio ini digunakan untuk mengukur seberapa lama waktu yang dibutuhkan perusahaan untuk menjual persediaannya. Semakin cepat perusahaan menjual persediaan maka mempengaruhi pula laba yang dihasilkan. Berikut ini disajikan perhitungan perputaran persediaan PT Unilever Indonesia Tbk tahun 2015-2019.

Tabel 5

Perputaran Persediaan PT Unilever Indonesia Tbk Tahun 2015-2019 (dalam jutaaan Rupiah)

\begin{tabular}{ccccccc}
\hline \multirow{2}{*}{ Tahun } & Harga & Pokok & $\begin{array}{c}\text { Persediaan } \\
\text { Awal }\end{array}$ & $\begin{array}{c}\text { Persediaan } \\
\text { Akhir }\end{array}$ & $\begin{array}{c}\text { Rata-Rata } \\
\text { Persediaan }\end{array}$ & \multicolumn{2}{c}{$\begin{array}{c}\text { Perputaran } \\
\text { Persediaan }\end{array}$} \\
\cline { 6 - 8 } & Penjualan & & & & Kali & Hari \\
\hline 2015 & $17,835,061$ & $2,325,989$ & $2,297,502$ & $2,311,746$ & 7.71 & 46.66 \\
2016 & $19,594,636$ & $2,297,502$ & $2,318,130$ & $2,307,816$ & 8.49 & 42.40 \\
2017 & $19,984,776$ & $2,318,130$ & $2,393,540$ & $2,355,835$ & 8.48 & 42.44 \\
2018 & $20,697,246$ & $2,393,540$ & $2,658,073$ & $2,525,807$ & 8.19 & 43.93 \\
2019 & $20,893,870$ & $2,658,073$ & $2,429,234$ & $2,543,654$ & 8.21 & 43.83
\end{tabular}

Sumber Data: Data Olahan, 2020 pengelolaan modal kerja, kebutuhan modal kerja, optimalisasi modal kerja. 


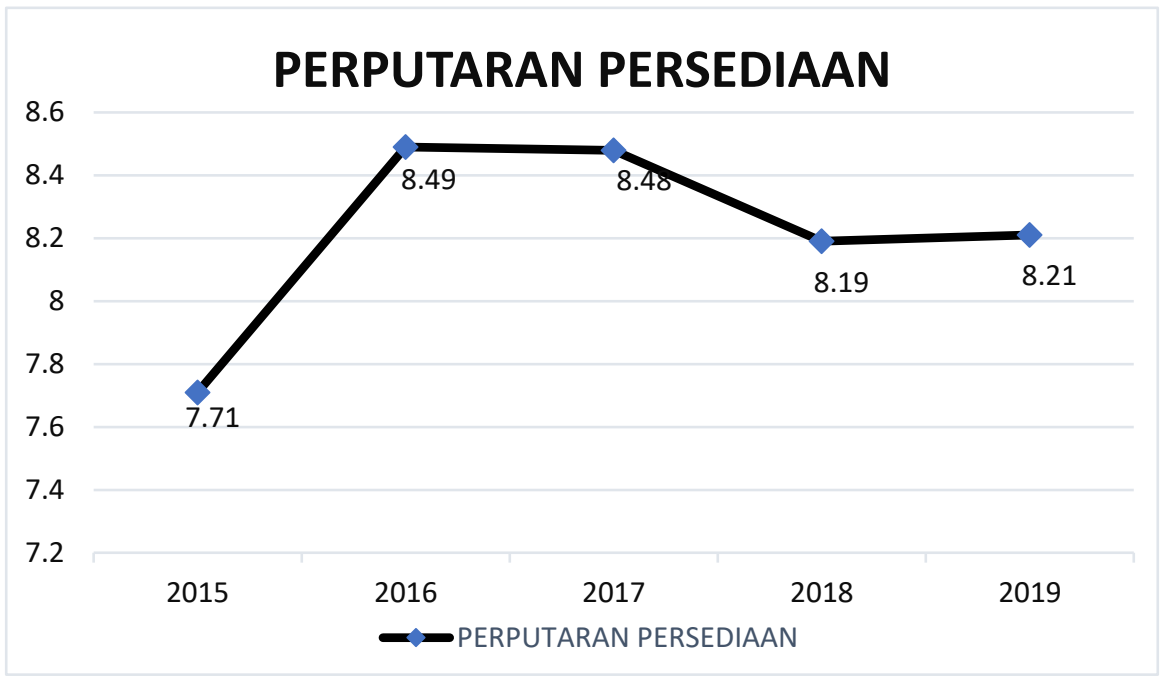

pengelolaan

modal kerja,

kebutuhan

modal kerja,

optimalisasi

modal kerja.

Gambar 3

Perputaran Persediaan PT Unilever Indonesia Tbk Tahun 2015-2019 Sumber : data olahan, 2020

Berdasarkan gambar 3 dapat dilihat bahwa kemampuan PT Unilever Indonesia Tbk. dalam melakukan perputaran Persediaan periode 2015-2019 berfluktuasi tiap tahunnya. Penurunan yang terjadi masih cukup stabil karena tidak terlalu signifikan. Penurunan ini menandakan terjadinya lambatnya dalam perputaran persediaan

Pada tahun 2015 perputaran persediaan sebanyak 7,71 kali atau rata-rata persediaan tersimpan di gudang sebelum dijual selama 46,66 hari. Pada tahun 2016 perputaran persediaan meningkat, yaitu sebanyak 8,49 kali atau rata-rata persediaan tersimpan di gudang sebelum dijual selama 42,40 hari. Pada tahun 2017 perputaran sebanyak 8,48 kali atau rata-rata persediaan tersimpan di gudang sebelum dijual selama 42,44 hari. Pada tahun 2018 perputaran persediaan menurun, yaitu sebanyak 8,19 kali atau ratarata persediaan tersimpan di gudang sebelum dijual selama 43,93 hari. Sedangkan tahun 2019 perputaran persediaan meningkat kembali, yaitu sebanyak 8,21 kali atau rata-rata persediaan tersimpan di gudang sebelum dijual selama 43,83 hari.

Setelah perputaran elemen modal kerja diketahui, kemudian dihitung kebutuhan modal kerja setiap tahunnya. Berikut ini disajikan perhitungan perputaran persediaan PT Unilever Indonesia Tbk tahun 2015-2019. 
Tabel 6

Kebutuhan Modal Kerja PT Unilever Indonesia Tbk Tahun 2015-2019 (dalam jutaaan Rupiah)

\begin{tabular}{|c|c|c|c|c|c|c|}
\hline & \multicolumn{3}{|c|}{ Periode Terikatnya Modal Kerja (kali) } & \multirow{2}{*}{$\begin{array}{l}\text { Perputaran } \\
\text { Modal Kerja (kali) }\end{array}$} & \multirow{2}{*}{$\begin{array}{l}\text { Penjualan } \\
\text { Bersih (Rp) }\end{array}$} & \multirow{2}{*}{$\begin{array}{l}\text { Kebutuhan } \\
\text { Modal Kerja (Rp) }\end{array}$} \\
\hline Tahun & Kas & Piutang Usaha & Persediaan & & & \\
\hline 2015 & - & - & - & - & - & - \\
\hline 2016 & 7.34 & 30.29 & 46.66 & 4.27 & $40,053,732$ & $9,378,136.31$ \\
\hline 2017 & 4.5 & 31.25 & 42.40 & 4.61 & $41,204,510$ & $8,944,812.38$ \\
\hline 2018 & 6.8 & 36.80 & 42.44 & 4.18 & $41,802,073$ & $9,990,695.45$ \\
\hline 2019 & 6.51 & 41.76 & 43.93 & 3.90 & $42,922,563$ & $10,992,945.30$ \\
\hline
\end{tabular}

pengelolaan modal kerja, kebutuhan modal kerja optimalisasi modal kerja

Sumber : data olahan, 2020

Berdasarkan tabel 6 di atas dapat dilihat bahwa kebutuhan akan modal kerja PT Unilever Indonesia Tbk tahun 2016-2019 cenderung meningkat. Jika dibandingkan dengan modal kerja yang tersedia (aset lancar), maka PT Unilever Indonesia mengalami kekurangan modal kerja dalam membiayai operasional perusahaan.

Pada tahun 2015 jumlah aset lancar sudah sebesar Rp 6,623,114 (dalam jutaan Rupiah), maka pada tahun 2016 perusahaan akan membutuhkan tambahan aktiva lancar sebesar Rp 2,755,022.31. Pada tahun 2016 jumlah aset lancar sudah sebesar Rp 6,588,100 (dalam jutaan Rupiah), maka pada tahun 2017 perusahaan akan membutuhkan tambahan aktiva lancar sebesar $\mathrm{Rp}$ 2,356,712.38 (dalam jutaan Rupiah). Pada tahun 2017 jumlah aset lancar sudah sebesar Rp 7,876,386 (dalam jutaan Rupiah), maka pada tahun 2018 perusahaan akan membutuhkan tambahan aktiva lancar sebesar Rp 2,114,309.45 (dalam jutaan Rupiah). Pada tahun 2018 jumlah aset lancar sudah sebesar Rp 8,257,910 (dalam jutaan Rupiah), maka pada tahun 2019 perusahaan akan membutuhkan tambahan aktiva lancar sebesar Rp 2,735,035.30 (dalam jutaan Rupiah).

Kekurangan modal kerja ini tentunya akan menyebabkan PT Unilever Indonesia Tbk mengalami masalah likuiditas, yaitu tidak mampu dalam membayar kewajiban jangka pendek dengan tepat pada waktunya. Perusahaan akan mencari kredit sebagai sumber dana guna memperbesar pemenuhan kebutuhan kekayaan aktiva lancar guna membeli bahan baku bahkan membayar gaji karyawan dan pengeluaran lainnya. 
Analisis Penentuan Modal Kerja Optimal pada PT Unilever Indonesia Tbk. Tahun 2015-2019.

Analisis Perputaran Modal Kerja

pengelolaan modal kerja, kebutuhan modal kerja, optimalisasi modal kerja. digunakan dalam mengukur keefektifan modal kerja perusahaan selama periode tertentu. Dalam arti, berapa banyak modal kerja berputar selama suatu periode tersebut.Untuk mengukur rasio ini kita membandingkan penjualan bersih dengan modal kerja atau dengan modal kerja rata-rata. Berikut ini disajikan tabel perhitungan Perputaran Modal Kerja PT Unilever Indonesia Tbk. Tahun 2015-2019:

Tabel 7

Perputaran Modal Kerja PT Unilever Indonesia Tbk Tahun 2015-2019 (dalam jutaaan Rupiah)

\begin{tabular}{llll}
\hline Tahun & \multicolumn{1}{l}{$\begin{array}{l}\text { Penjualan } \\
\text { Bersih }\end{array}$} & $\begin{array}{l}\text { Aset } \\
\text { Lancar }\end{array}$ & $\begin{array}{l}\text { Perputaran Modal Kerja } \\
\text { (kali) }\end{array}$ \\
\hline 2015 & $36,484,030$ & $6,623,114$ & 5.51 \\
2016 & $40,053,732$ & $6,588,100$ & 6.08 \\
2017 & $41,204,510$ & $7,876,386$ & 5.23 \\
2018 & $41,802,073$ & $8,257,910$ & 5.06 \\
2019 & $42,922,563$ & $8,530,334$ & 5.03 \\
\hline
\end{tabular}

Sumber : data olahan, 2020

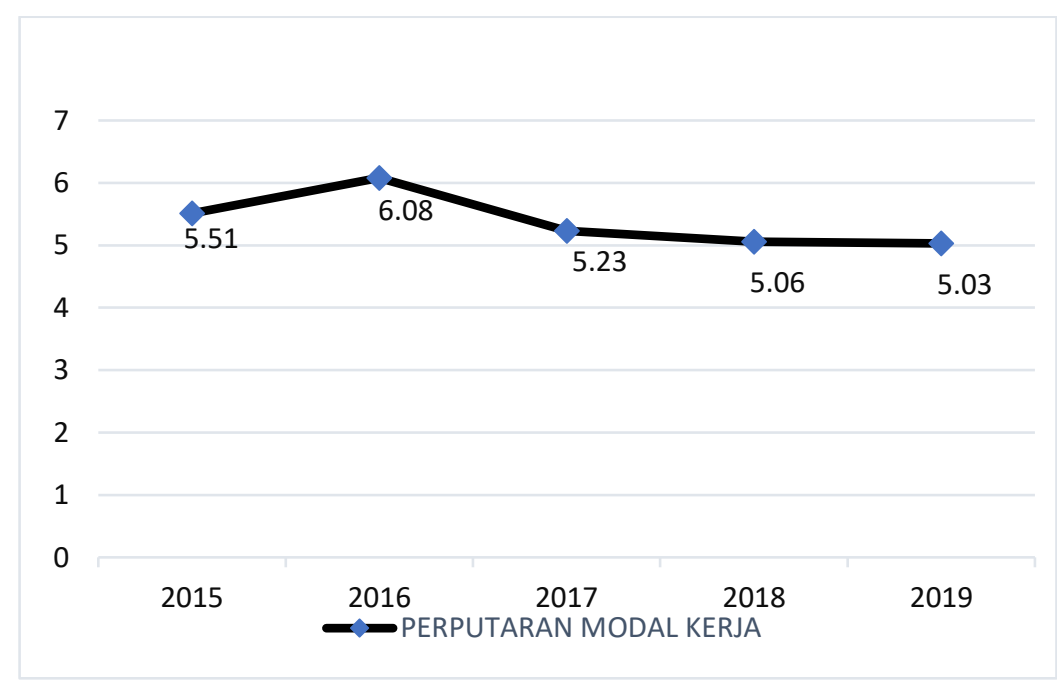

Gambar 4

Perputaran Modal Kerja PT Unilever Indonesia Tbk Tahun 2015-2019 Sumber : data olahan, 2020 
Berdasarkan gambar 4 dapat dilihat bahwa kemampuan PT Unilever Indonesia Tbk. dalam melakukan perputaran modal kerja periode 2015-2019 cenderung menurun. Pada tahun 2015, kemampuan modal kerja dalam menghasilkan penjualan sebesar 5,51 kali dalam setahun. Pada tahun 2016, modal kerja berputar sebanyak 6,08 kali dalam setahun. Kenaikan jumlah perputaran dikarenakan adanya selisih berupa kenaikan pada pengelolaan modal kerja, kebutuhan modal kerja, optimalisasi modal kerja.

Penjualan bersih sebesar $8,91 \%$, dan adanya selisih berupa penurunan pada aset lancar sebesar $0,53 \%$ sehingga pada tahun ini setiap 1 rupiah modal kerja dapat menghasilkan 6,08 rupiah penjualan.

Pada tahun 2017, modal kerja berputar sebanyak 5,23 kali dalam setahun. Penurunan jumlah perputaran dikarenakan adanya kenaikan pada Penjualan Bersih sebesar 2,79\%. Kenaikan juga terjadi pada aset lancar sebesar 16,36\%. Persentase kenaikan pada aset lancar lebih tinggi dibandingkan dengan persentase kenaikan pada Penjualan bersih, sehingga pada tahun ini setiap 1 rupiah modal kerja dapat menghasilkan 5,23 rupiah penjualan.

Pada tahun 2018, modal kerja berputar sebanyak 5,06 kali dalam setahun. Penurunan jumlah perputaran dikarenakan adanya kenaikan pada Penjualan Bersih sebesar 1,43\%. Kenaikan juga terjadi pada aset lancar sebesar 4,62\%. Persentase kenaikan pada aset lancar lebih tinggi dibandingkan dengan persentase kenaikan pada Penjualan bersih, sehingga pada tahun ini setiap 1 rupiah modal kerja dapat menghasilkan 5,06 rupiah penjualan.

Pada tahun 2019, modal kerja berputar sebanyak 5,03 kali dalam setahun. Penurunan jumlah perputaran dikarenakan adanya kenaikan pada Penjualan Bersih sebesar 2,61\%. Kenaikan juga terjadi pada aset lancar sebesar 3,19\%. Persentase kenaikan pada aset lancar lebih tinggi dibandingkan dengan persentase kenaikan pada Penjualan bersih, sehingga pada tahun ini setiap 1 rupiah modal kerja dapat menghasilkan 5,03 rupiah penjualan.

\section{Analisis Modal Kerja Optimal}

Modal kerja optimal adalah kemampuan perusahaan untuk memaksimalkan hasil (output), dalam arti tidak terjadi kelebihan atau kekurangan modal kerja, sehingga pada tingkat modal kerja optimal yaitu biaya akan sama dengan manfaatnya. Berikut ini 
disajikan tabel perhitungan Modal Kerja Optimal PT Unilever Indonesia Tbk. Tahun 2015-2019:

Tabel 8

Modal Kerja Optimal PT Unilever Indonesia Tbk Tahun 2015-2019 (dalam jutaan Rupiah)

\begin{tabular}{|c|c|c|c|c|c|}
\hline \multirow{3}{*}{ Tahun } & Penjualan & \multicolumn{2}{|l|}{ Perputaran } & \multirow{3}{*}{$\begin{array}{l}\text { Modal } \\
\text { Kerja Riil }\end{array}$} & \multirow[t]{3}{*}{ Keterangan } \\
\hline & Bersih yang & Modal & Modal Kerja & & \\
\hline & akan datang & Kerja (kali) & Optimal & & \\
\hline \multirow{2}{*}{2015} & \multirow{2}{*}{$40,053,732$} & & & & Belum \\
\hline & & 5.51 & $7,271,138.44$ & $6,623,114$ & optimal \\
\hline \multirow{2}{*}{2016} & \multirow{2}{*}{$41,204,510$} & & & & Belum \\
\hline & & 6.08 & $6,777,381.75$ & $6,588,100$ & optimal \\
\hline \multirow{2}{*}{2017} & \multirow{2}{*}{$41,802,073$} & & & & Belum \\
\hline & & 5.23 & $7,990,612.25$ & $7,876,386$ & optimal \\
\hline \multirow{2}{*}{2018} & \multirow{2}{*}{$42,922,563$} & & & & Belum \\
\hline & & 5.06 & $8,479,260.40$ & $8,257,910$ & optimal \\
\hline 2019 & - & 5.03 & - & $8,530,334$ & - \\
\hline
\end{tabular}

pengelolaan modal kerja, kebutuhan modal kerja, optimalisasi modal kerja.

Sumber : data olahan, 2020

Keterangan:

Optimal : Jika $M K R=M K O$

Belum Optimal: Jika MKR $\neq M K O ; M K R>M K O ; M K R<M K O$

Berdasarkan tabel 8 di atas, dapat dilihat bahwa kemampuan PT Unilever Indonesia Tbk. dalam menentukan modal kerja optimal periode tahun 2015-2018 cenderung meningkat. Modal kerja riil yang ada pada perusahaan belum optimal dari tahun 20152018 di mana modal kerja riil tidak sama dengan modal kerja optimal yang diperoleh. Modal kerja riil kurang dari modal kerja optimal akan menghambat atau menganggu kelancaran proses produksi atau operasional karena perusahaan kekurangan dana.

Pada tahun 2015, modal kerja riil bernilai kurang dari modal kerja optimal, yaitu sebesar Rp 6,623,114 sedangkan modal kerja yang optimal sebesar Rp 7,271,138.44. Pada tahun 2016 modal kerja riil bernilai kurang dari modal kerja optimal, yaitu sebesar Rp 6,588,100 sedangkan modal kerja yang optimal sebesar Rp 6,777,381.75. Walaupun modal kerja riil yang ada belum optimal, namun jumlah yang diperoleh tidak jauh 
menurun dari modal kerja optimal yang seharusnya. Selisih antara modal kerja riil dan modal kerja optimal adalah sebesar Rp 189,281.75. Pada tahun 2017 modal kerja riil bernilai kurang dari modal kerja optimal, yaitu sebesar Rp 7,876,386 sedangkan modal kerja yang optimal sebesar Rp 7,990,612.25. Walaupun modal kerja riil yang ada belum optimal, namun jumlah yang diperoleh tidak jauh menurun dari modal kerja optimal pengelolaan modal kerja, kebutuhan modal kerja, optimalisasi modal kerja. yang seharusnya. Selisih antara modal kerja riil dan modal kerja optimal adalah sebesar Rp 114,226.25. Begitu pula pada tahun 2018 modal kerja riil bernilai kurang dari modal kerja optimal, yaitu sebesar Rp 8,257,910 sedangkan modal kerja yang optimal sebesar Rp 8,479,260.40 Walaupun modal kerja riil yang ada belum optimal, namun jumlah yang diperoleh tidak jauh menurun dari modal kerja optimal yang seharusnya. Selisih antara modal kerja riil dan modal kerja optimal adalah sebesar Rp 221,350.40.

\section{SIMPULAN DAN SARAN}

\section{Simpulan}

Berdasarkan hasil analisis optimalisasi modal kerja pada PT Unilever Indonesia Tbk. tahun 2015-2019 menggunakan rasio-rasio keuangan, maka dapat disimpulkan bahwa:

1. Kebutuhan modal kerja PT Unilever Indonesia Tbk tahun 2016-2019 cenderung meningkat. Jika dibandingkan dengan modal kerja yang tersedia (aset lancar), maka PT Unilever Indonesia mengalami kekurangan modal kerja dalam membiayai operasional perusahaan. Kekurangan modal kerja ini tentunya akan menyebabkan PT Unilever Indonesia Tbk mengalami masalah likuiditas, yaitu tidak mampu dalam membayar kewajiban jangka pendek dengan tepat pada waktunya. Perusahaan akan mencari kredit sebagai sumber dana guna memperbesar pemenuhan kebutuhan kekayaan aktiva lancar guna membeli bahan baku bahkan membayar gaji karyawan dan pengeluaran lainnya.

2. Modal kerja optimal PT Unilever Indonesia Tbk tahun 2015-2018 cenderung meningkat. Modal kerja riil yang ada pada perusahaan belum optimal dari tahun 2015-2018 di mana modal kerja riil tidak sama dengan modal kerja optimal yang diperoleh. Modal kerja riil kurang dari modal kerja optimal akan menghambat atau menganggu kelancaran proses produksi atau operasional karena perusahaan kekurangan dana. Walaupun modal kerja riil yang ada belum optimal, namun 
jumlah yang diperoleh tidak jauh menurun dari modal kerja optimal yang seharusnya

Saran

pengelolaan modal kerja, kebutuhan modal kerja, optimalisasi modal kerja.

Berdasarkan kesimpulan di atas, maka penulis ingin memberikan saran kepada beberapa pihak sebagai berikut:

1. Bagi investor, hasil penelitian diharapkan dapat digunakan sebagai tolak ukur dalam mengambil keputusan investasi saham, dengan melihat kepada perhitungan modal kerja, tingkat keuntungan dan kemampuan pemenuhan kewajiban perusahaan pada saat ingin berinvestasi.

2. Bagi perusahaan, diharapkan hasil penelitian dapat dijadikan bahan evaluasi dalam mengelola modal kerja yang dimiliki, seperti memaksimalkan kemampuan dalam menggunakan modal kerja yang tersedia, sehingga modal kerja dapat berputar lebih cepat dan memiliki tingkat likuiditas yang lebih baik

\section{DAFTAR PUSTAKA}

Agus Purwanto, Erwan dan Ratih Sulistyastuti, Dyah. 2017. Metode Penelitian Kuantitatif untuk Administrasi Publik dan Masalah-Masalah Sosial. Edisi 2 Cetakan 1. Yogyakarta: Gava Media.

Bringham dan Houston. 2011. Dasar-dasar Manajemen Keuangan. Edisi 2. Salemba Empat. Jakarta.

Kasmir. 2015. Analisis Laporan Keuangan. Edisi 1. Cetakan ke-8. Jakarta: Rajawali Pers.

Tampubolon, Manahan P. 2005. Manajemen Keuangan (Finance Management).Cetakan Pertama. Bogor: Ghalia Indonesia.

Muchson, M. 2015. Accounting Research Methodology Textbook Development to Provide College Students in Accounting Subject. In Prosiding Seminar Nasional Pendidikan Akuntansi dan Keuangan.

Sugiyono. 2005. Metode Penelitian Bisnis (Pendekatan Kuantitatif, Kualitatif dan R\&D). Bandung: Alfabeta.

Sutrisno. 2005. Manajemen keuangan (Teori, Konsep dan Aplikasi). Cetakan Keempat.Yogyakarta: Ekonosia. 